\title{
Hubungan frekuensi pemberian makanan dan riwayat asi eksklusif dengan kejadian stunting pada baduta di desa parappe
}

\author{
Mirnawati $^{1)}$, Rahmaniah ${ }^{2)}$ \\ 1) Prodi S1 Kesehatan Masyarakat Stikes Bina Bangsa Majene \\ ${ }^{2)}$ Prodi S1 Keperawatan Universitas Sulawesi Barat
}

Keywords :

Knowledge, Trust, and Personal Hygiene

\section{Kontak :}

Rahmaniah

Email : rahmaniahfikes@ unsulbar.ac.id 'Prodi S1 Keperawatan Universitas Sulawesi Barat

DOI : https://doi.org/10.15294/ kemas.v14i3.1562

(C)2020J-Healt

ini adalah artikel dengan akses terbuka dibawah licenci CC BY-NC-4.0

https://creativecommons.org/licenses/by-nc/4.0/

\begin{abstract}
Stunting on children under two years is a chronic nutritional problem that is still a concern in Indonesia. Stunting estimates the cumulative effect of a long-term deficiency or inadequate intake of energy, macro and micro nutrients or the result of chronic infections or infections that occur repeatedly. Among the factors that influence the incidence of stunting are the frequency of feeding and assessment of exclusive breastfeeding. In Indonesia the stunting prevalence in 2013 was 37.2\%, in West Sulawesi was $47.0 \%$ and West Sulawesi was the second highest after East Nusa Tenggara. In Polewali Mandar the number of stunting is 300 toddlers. The working area of the Campalagian Community Health Center is in the second stunting position after Tutar with the number of stunting toddlers 53, consisting of 35 million and 18 over two. In Campalagian Subdistrict of the 13 existing villages, Parappe Village is the village with the highest percentage of stunting on children under two years. The purpose of this study was to study the relationship between feeding and publication of Asians with the occurrence of stunting in Buta. This type of observational research with cross sectional design. The study population was 193 million in the working area of the Campalagian Health Center. The study sample was 65 million people in Parappe Village. Data on frequency of feeding and exclusive breastfeeding surveys were obtained using a questionnaire, while stunting data was obtained from the measurement results. The technique of taking samples using purposive sampling. Data analysis with chisquare test. Based on the analysis results obtained from the frequency of feeding with stunting $(\mathrm{p}=0.12)$ and exclusive breastfeeding surveys with stunting $(p=0.10)$. Means $p>\alpha=0.05$, so there is no relationship between the frequency of feeding and the exclusive breastfeeding edition with the occurrence of stunting children under two years. Complementary breastfeeding in terms of quality both the amount and pattern of giving complementary breastfeeding that is appropriate for the age of the child.
\end{abstract}




\section{PENDAHULUAN}

Secara garis besar, masalah gizi merupakan dampak dari ketidakseimbangan antara asupan dan keluaran zat gizi (nutritional imbalance), yaitu asupan yang melebihi keluaran atau sebaliknya (Kemenkes, 2015). Di Indonesia, spektrum malnutrisi sangat luas dan terjadi di seluruh tahap kehidupan antara lain bentuk Kurang Energi Protein (KEP), kekurangan zat gizi mikro, berat bayi lahir rendah dan gangguan pertumbuhan yang dapat dilihat dari indikator Tinggi/Panjang Badan menurut Umur (TB/U atau $\mathrm{PB} / \mathrm{U})$. Gangguan pertumbuhan berdasarkan indikator $\mathrm{TB} / \mathrm{U}$ atau $\mathrm{PB} / \mathrm{U}$ dari segi asupan gizi, mengindikasikan efek kumulatif dari kekurangan atau ketidakcukupan asupan energi, zat gizi makro dan zat gizi mikro dalam jangka panjang atau hasil dari infeksi kronis atau infeksi yang terjadi berulang kali, yang kemudian disebut pendek (stunting) (Anwar, dkk, 2013).

Baduta merupakan kelompok usia 0-24 bulan yang berada pada periode emas kehidupan. Baduta rawan terhadap masalah stunting jika asupan gizi tidak tercukupi. Secara umum menurut Su'adi disitasi oleh Sakti (2013) mengemukakan bahwa seseorang yang stunting kemungkinan keadaan gizi masa lalu tidak baik. Berbeda dengan berat badan yang dapat diperbaiki dalam waktu singkat, baik pada anak maupun dewasa. Maka, tinggi badan pada usia dewasa tidak dapat lagi dinormalkan Selain itu, Stunting juga berkolerasi dengan gangguan perkembangan nuerokognitif dan resiko penyakit tidak menular dimasa depan (Kementerian Kesesehatan/Kemenkes, 2015).

Menurut United Nations Children's Fund/UNICEF disitasi oleh Pengan, dkk (2015) bahwa pada tahun 2011 ada 165 juta (26\%) balita dengan status gizi stunting di seluruh dunia. Sub-Sahara Afrika dan Asia Selatan merupakan daerah terbanyak didunia dengan status stunting. Di Sub-Sahara Afrika terdapat $40 \%$ balita stunting dan di Asia Selatan $39 \%$ balita stunting. Indonesia termasuk dalam 5 negara dengan angka balita stunting tertinggi yaitu sebanyak 7,5 juta balita, sehingga keadaan gizi kurang kronis tetap merupakan permasalahan yang sangat penting.

Berdasarkan hasil penelitian Sumartini disitasi oleh Sakti (2013) yang dilakukan di Kecamatan Medan Amplas menunjukkan bahwa pola pemberian MP ASI meliputi jenis makanan tambahan, konsumsi energi dan protein serta frekuensi konsumsi makan berpengaruh terhadap status gizi bayi usia 612 bulan. Penelitian yang sama dilakukan Lestari, dkk (2014) di Kota Subulussalam menunjukkan bahwa praktek pemberian makanan (frekuensi makan dan jumlah makanan) yang kurang baik akan berisiko terhadap kejadian stunting. Stunting juga dipengaruhi oleh riwayat pemberian ASI eksklusif. Anak yang tidak mendapatkan ASI eksklusif berisiko lebih tinggi untuk kekurangan zat gizi yang diperlukan untuk pertumbuhan (Anshori, 2013).

Prevalensi stunting secara nasional sebesar $37,2 \%$ yang berarti terjadi peningkatan dari tahun 2010 yang hanya 35,6\%. Di Sulawesi Barat prevalensi stunting melampaui prevalensi nasional yaitu $47,0 \%$. Stunting di Sulawesi Barat menempati urutan kedua tertinggi setelah Nusa Tenggara Timur (Kemenkes, 2013). Berdasarkan data Dinas Kesehatan Polewali Mandar (2015) menunjukkan bahwa jumlah stunting sebanyak 300 balita. Wilayah kerja Puskesmas Campalagian berada diurutan kedua tertinggi stunting setelah Tutar dengan jumlah balita stunting sebanyak 53 balita, yang terdiri dari 35 baduta dan 18 diatas baduta, dari 13 desa yang ada di 4 Kecamatan Campalagian, Desa Parappe merupakan desa dengan persentase tertinggi stunting baduta (Data Puskesmas Campalagian, 2016).

Berdasarkan latar belakang tersebut, maka tujuan penelitian ini adalah untuk mengetahui hubungan frekuensi pemberian makanan dan riwayat ASI eksklusif dengan stunting usia 623 bulan di Desa Parappe. 


\section{METODE}

Jenis penelitian ini adalah observasional dengan desain cross sectional yang dilakukan di Desa Parappe Kecamatan Campalagian Kabupaten Polewali Mandar pada bulan Juni sampai Juli 2016. Populasinya adalah seluruh Baduta sebanyak 193 orang yang berada di wilayah kerja Puskesmas Campalagian. Sampel penelitian adalah baduta di Desa Parappe sebanyak 65 orang yang didapatkan dengan menggunakan tekhnik pengambilan sampel purposive sampling. Variabel independen berupa frekuensi pemberian makanan dan riwayat ASI eksklusif dan variabel dependennya adalah stunting. Data frekuensi pemberian makanan dan riwayat ASI eksklusif diperoleh dengan menggunakan kuesioner. Data stunting baduta diperoleh dari hasil pengukuran panjang badan menggunakan length board dan data umur dengan menggunakan wawancara kemudian data tersebut dibandingkan dengan standar WHO antro 2005. Analisis univariat digunakan untuk mengetahui distribusi karakteristik responden dan analisis hubungan antar variabel diketahui dengan menggunakan uji chi square.

\section{HASIL}

Hasil penelitian menunjukkan bahwa terdapat $33.8 \%$ responden yang mengalami stunting dan $66.2 \%$ responden status gizi normal. Berdasarkan variabel jenis kelamin, $53.8 \%$ baduta berjenis kelamin laki-laki dan $46.2 \%$ perempuan. Variabel umur, $78.5 \%$ baduta berumur $9-23$ bulan dan $21.5 \%$ berumur $6-8$ bulan. Pada variabel frekuensi pemberian makanan, terdapat $69.2 \%$ yang memenuhi dan $30.8 \%$ tidak memenuhi frekuensi pemberian makanannya, dan dari segi riwayat ASI eksklusif, terdapat $61,5 \%$ yang mendapat ASI eksklusif dan $38.5 \%$ yang tidak ASI eksklusif. (Tabel 1).
Tabel 1. Distribusi Karakteristik Baduta

\begin{tabular}{lcc}
\hline \multicolumn{1}{c}{ Variabel } & $\mathbf{n}=\mathbf{6 5}$ & $\mathbf{\%}$ \\
\hline $\begin{array}{l}\text { Status Gizi } \\
\quad \text { Stunting } \\
\quad \text { Normal }\end{array}$ & 22 & 33.8 \\
\hline Jenis Kelamin & 43 & 66.2 \\
$\quad$ Laki-laki & & \\
$\quad$ Perempuan & 35 & 53.8 \\
\hline $\begin{array}{l}\text { Umur (bulan) } \\
\quad \text { 6-8 }\end{array}$ & 30 & 46.2 \\
$\quad$ 9-23 & 14 & 21.5 \\
\hline $\begin{array}{l}\text { Frekuensi Pemberian } \\
\text { Makanan }\end{array}$ & 51 & 78.5 \\
$\quad$ Memenuhi & 45 & 69.2 \\
$\quad$ Tidak Memenuhi & 20 & \\
\hline $\begin{array}{l}\text { Riwayat ASI eksklusif } \\
\quad \text { ASI Eksklusif }\end{array}$ & & \\
$\quad$ Tidak ASI eksklusif & 25 & \\
\hline
\end{tabular}

Hasil analisis uji Chi square (Tabel 2) menunjukkan bahwa tidak terdapat hubungan antara frekuensi pemberian makanan dengan kejadian stunting pada Baduta $(\mathrm{p}=0.12)$ dan riwayat ASI eksklusif juga tidak berhubungan dengan kejadian stunting $(\mathrm{p}=0.10)$. Berarti $p>\alpha=0,05$. Hal ini berarti bahwa tidak ada hubungan yang signifikan antara frekuensi pemberian makanan dan riwayat ASI eksklusif dengan kejadian stunting pada Baduta di Desa Parappe Kecamatan Campalagian Kabupaten Polewali Mandar. Pada penelitian ini terlihat bahwa yang tidak memenuhi frekuensi pemberian makanan dan mengalami stunting sebanyak $50 \%$ dan berstatus gizi normal 50\%, sedangkan yang memenuhi frekuensi pemberian makanan tetapi stunting sebanyak $26.7 \%$ dan status gizi normal sebanyak $73.3 \%$. Begitu pula dengan variabel riwayat ASI eksklusif, Baduta yang tidak ASI eksklusif $48 \%$ mengalami stunting, sedangkan yang berstatus gizi normal $52 \%$. Tetapi terdapat pula Baduta yang mendapat ASI eksklusif tetapi mengalami stunting $(25 \%)$ dan yang berstatus gizi normal sebanyak $75 \%$. Oleh karena tidak ada hubungannya antara frekuensi pemberian makanan dan riwayat ASI eksklusif dengan kejadian stunting, maka bisa jadi ada faktor 
lain yang ikut terlibat dalam kejadian stunting Baduta tersebut.

\section{Tabel 2. Analisis Bivariat Variabel}

\section{Independen terhadap Stunting}

\begin{tabular}{|c|c|c|c|c|c|}
\hline \multirow{3}{*}{ Variabel } & \multicolumn{4}{|c|}{ Status Gizi } & \multirow{3}{*}{$\mathbf{p}$} \\
\hline & \multicolumn{2}{|c|}{ Stunting } & \multicolumn{2}{|c|}{ Normal } & \\
\hline & $\mathbf{n}$ & $\%$ & $\mathbf{n}$ & $\%$ & \\
\hline \multirow{2}{*}{\multicolumn{6}{|c|}{$\begin{array}{l}\text { Frekuensi } \\
\text { Pemberian }\end{array}$}} \\
\hline & & & & & \multirow{4}{*}{0.12} \\
\hline $\begin{array}{l}\text { Makanan } \\
\text { Tidak }\end{array}$ & & & & & \\
\hline Memenuhi & 10 & 50 & 10 & 50 & \\
\hline Memenuhi & 12 & 26.7 & 33 & 73.3 & \\
\hline \multicolumn{6}{|l|}{$\begin{array}{ll}\begin{array}{l}\text { Riwayat } \\
\text { eksklusif }\end{array} & \text { ASI }\end{array}$} \\
\hline Tidak ASI & & & & & \multirow[t]{3}{*}{0.10} \\
\hline eksklusif & 12 & 48.0 & 13 & 52.0 & \\
\hline ASI eksklusif & 10 & 25.0 & 30 & 75.0 & \\
\hline
\end{tabular}

\section{PEMBAHASAN}

Berdasarkan hasil penelitian menunjukkan bahwa tidak terdapat hubungan yang signifikan antara frekuensi pemberian makanan dengan kejadian stunting pada Baduta. Hal ini karena, pada penelitian yang diteliti, hanya frekuensi pemberian makan dan tidak meneliti tentang jumlah dan variasi makanan yang diberikan kepada baduta. Hasil penelitian ini sejalan yang dilakukan oleh Yuanita dkk (2013) yang menyatakan bahwa tidak ada hubungan frekuensi makan bayi pada usia 6-12 bulan di Desa Pamongan Wilayah Puskesmas Guntur Dua Kabupaten Demak. Sugihantono (2014) juga menyatakan bahwa frekuensi pemberian makan pada baduta juga harus melihat jumlah dan variasi makanan yang diberikan. Jumlah dan variasi makanan mempengaruhi status gizi sehingga, meskipun frekuensinya baik tetapi jumlah dan variasi yang diberikan belum sesuai dengan anjuran maka anak akan berisiko mengalami gangguan gizi.

Berdasarkan hasil penelitian, ibu baduta memberikan makanan pada anaknya sesuai jadwal makan keluarga, tetapi jumlah makanan yang diberikan belum mencukupi kebutuhan baduta. Meskipun frekuensi pemberian makan sesuai, tapi jumlah atau porsi yang diberikan belum cukup, tetap tidak akan mempengaruhi status gizi (PB/U) baduta. Selain itu, makanan yang diberikan ibu kepada baduta kurang bervariasi. Menu yang diberikan hampir sama setiap hari. Baduta tidak diajarkan berbagai variasi makanan yang kemudian mempersempit cita rasa baduta untuk mengenal berbagai variasi makanan. Variasi makanan yang kurang, tidak akan memenuhi kebutuhan makro dan mikro nutrien baduta. Sehingga, meskipun frekuensi pemberian makan yang diberikan sesuai, namun jumlah dan variasi makanan yang diberikan belum mampu memcukupi kebutuhan gizi.

Secara umum status gizi secara langsung dipengaruhi oleh asupan makanan (intake). Sehingga, makanan yang diberikan kepada anak harus memadai dalam hal kuantitas dan kualitas makanan. Kuantitas yang dimaksud seperti jumlah atau porsi makanan dan frekuensi pemberian makan. Kualitas yang dimaksud seperti variasi makanannya (Nurlinda, 2012). Frekuensi makanan yang dibutuhkan oleh anak untuk mencapai energi yang dianjurkan, tergantung pada kepadatan energi dari makanan, karena lambung anak ukurannya kecil, maka pemberian makan yang sering adalah penting. Anak yang tidak menyusu lagi membutuhkan makanan yang sering dan dalam jumlah lebih banyak, dengan memberikan perhatian khusus pada kualitas protein, mikronutrien dan energi dari makanan (Isianty dan Rusilanti, 2013).

Variabel riwayat ASI eksklusif juga tidak terdapat hubungan yang signifikan dengan kejadian stunting. Hal ini karena, lama atau durasi pemberian ASI tidak sesuai dengan anjuran, yaitu 7-8 kali perhari dan diberikan setiap 2-3 jam. Ibu hanya akan memberikan ASI pada saat anaknya menangis. Setelah ibu merasa anaknya sudah kenyang, pemberian ASInya pun dilepaskan. Selain itu, Pada saat ibu melahirkan waktu IMD (Inisiasi Menyusu Dini) bayi tidak cukup satu jam. World Health Organization (WHO) dan UNICEF disitasi Maryunani (2012) menyatakan bahwa waktu IMD bayi setelah kelahiran adalah satu jam untuk memperoleh kolostrum yang berwarna 
kuning dan banyak mengandung antibody. Sehingga, meskipun bayi diberi ASI eksklusif tetap tidak akan berhubungan dengan stunting karena durasi pemberian ASI dan IMD bayi yang diberikan kurang satu jam.

Soetjiningsih dan Wahyunur (2014) menyatakan bahwa memberikan ASI pada bayi sebaiknya sesering mungkin karena bayi akan menentukan sendiri kebutuhannya. Ibu harus menyusui bayinya bila bayi menangis bukan karena sebab lain (kencing, dan lainlain) atau ibu sudah merasa sudah perlu menyusui bayinya. Bayi yang sehat dapat mengosongkan satu payudara sekitar 5-7 menit dan ASI dalam lambung bayi akan kosong dalam waktu 2 jam. Pada hari pertama, biasanya ASI belum keluar, bayi cukup disusukan selama 4-5 menit, untuk merangsang produksi ASI dan membiasakan putting susu dihisap oleh bayi. Setelah hari ke 4-5, boleh disusukan selama 10 menit. Setelah produksi ASI cukup, bayi dapat disusukan selama 15 menit (jangan lebih dari 20 menit). Menyusukan selama 15 menit ini jika produksi ASI cukup dan ASI lancar keluarnya, sudah cukup untuk bayi. Dikatakan bahwa, jumlah ASI yang terisap bayi pada 5 menit pertama adalah $\pm 112 \mathrm{ml}, 5$ menit kedua $\pm 64 \mathrm{ml}$ dan 5 menit terakhir hanya $\pm 16 \mathrm{ml}$.

Penelitian ini sejalan dengan hasil penelitian di Kabupaten Pati, yang menyatakan bahwa pemberian ASI eksklusif bukan merupakan faktor resiko terjadinya stunting pada anak usia 12-36 bulan di Kecamatan Pati, Kabupaten Pati. Hasil penelitian sama, yang dilakukan oleh Winny, dkk (2014) pada 96 sampel dengan menggunakan metode observasional melalui pedekatan retrospektif di wilayah kerja Puskesmas Kawangkoan menunjukkan bahwa tidak terdapat hubungan antara riwayat ASI eksklusif dengan status gizi (indeks $\mathrm{PB} / \mathrm{U}$ ).

\section{KESIMPULAN}

Tidak terdapat hubungan yang signifikan antara frekuensi pemberian makanan dan riwayat ASI eksklusif dengan kejadian stunting pada Baduta di Desa Parappe Kecamatan Campalagian Kabupaten Polewali Mandar. Sehingga disarankan terhadap petugas gizi di Puskesmas Campalagian agar meningkatkan penyuluhan kesehatan kepada ibu yang memiliki anak usia 6-23 bulan tentang pentingnya pemberian makanan pendamping ASI (MP ASI) dari segi kualitas maupun kuantitas dan pola pemberian MP ASI yang sesuai dengan umur anak.

\section{DAFTAR PUSTAKA}

Anshori, H. 2013. Faktor resiko kejadian stunting pada anak usia 12-24 bulan (studi di Kecamatan Semarang Timur). Tidak diiterbitkan.

Anwar, dkk. 2013. Kaitan antara status gizi, perkembangan kognitif dan perkembangan motorik pada anak usia prasekolah di desa cibanteng kabupaten bogor jawa barat. Jurnal Penelitian Gizi dan Makanan.

Departemen Kesehatan RI. 2007. Pedoman Gizi Seimbang. Departemen Kesehatan. Jakarta.

Dinas Kesehatan Kabupaten Polewali Mandar. 2015. Rekapitulasi Data Gizi 2015.

Istiany, A. dan Rusilanti. 2013 .Gizi Terapan. Edisi Pertama. PT. Remaja Rosdakarya. Bandung.

Kementerian Kesehatan RI. 2013. Riset Kesehatan Dasar Tahun. www.depkes.go.id, resources, download > general > Hasil Riskesdas

Kementerian Kesehatan RI. 2015. Pusat data dan informasi. Infodatin. (online), (www.depkes.go.id.>infodatin-gizi diakses 12 oktober 2015).

Lestari, W, dkk. 2014. Faktor risiko stunting pada anak umur 6-24 bulan di kecamatan penanggalan kota subulussalam provinsi Aceh. Jurnal Gizi Indonesia.

Maryunani, A. 2012. Inisiasi Menyusu Dini, ASI Eksklusif dan Manajemen Laktasi. 
Edisi Pertama. CV Trans Info Media. Jakarta.

Nurlinda, A. 2012. Gizi dalam daur kehidupan seri baduta. Edisi Pertama. CV andi offset. Makassar.

Pengan, dkk. 2015. Hubungan antara riwayat pemberian ASI eksklusif dengan kejadian stunting pada anak usia 12-36 bulan di wilayah kerja puskesmas luwuk kecamatan luwuk selatan kabupaten banggai Sulawesi tengah. Jurnal Johan.

Puskesmas Campalagian. 2016. Data Balita bulan januari sampai april.

Sakti, R.E. 2013. Hubungan pola pemberian MP ASI dengan status gizi anak usia 623 bulan di wilayah pesisir kecamatan Tallo kota Makassar. Tidak diterbitkan.

Sugihantono, A. 2014. Pedoman Gizi Seimbang verbal. Jakarta.

Winny, dkk. 2104. Hubungan antara riwayat pemberian ASI eksklusif dengan kejadian stunting pada anak batita di wilayah kerja Puskesmas Kawangkoan kabupaten minahasa. Tidak diterbitkan.

Yuanita, dkk. 2013. Hubungan pola makan dengan status gizi pada bayi usia 6-12 bulan di desa pamongan wilayah puskesmas guntur II kabupaten demak. Jurnal Kebidanan Panti Wilasa. 